\title{
Adipogenesis and aldosterone: a study in lean tryptophan-depleted rats
}

\author{
Michal Pokusa ${ }^{1}$, Natasa Hlavacova ${ }^{1}$, Agnesa Csanova ${ }^{1}$, Michael Franklin ${ }^{2}$, Stefan Zorad ${ }^{1}$ \\ and Daniela Jezova ${ }^{1}$ \\ ${ }^{1}$ Laboratory of Pharmacological Neuroendocrinology and Laboratory of Metabolic Regulations, Institute of Experimental \\ Endocrinology, Biomedical Research Center, Slovak Academy of Sciences, Bratislava, Slovak Republic \\ ${ }^{2}$ School of Life Sciences, Oxford Brookes University, Oxford OX3 OBP, United Kingdom
}

\begin{abstract}
Next to epithelial tissues, mineralocorticoid receptors are also expressed in adipose tissue and are involved in the process of adipogenesis. Mineralocorticoid receptors in adipose tissue are likely to be activated mainly by glucocorticoids. The aim of the present study was to test the hypothesis that the processes related to adipogenesis are modified under the conditions associated with high circulating aldosterone. We have made advantage of a model of depression based on tryptophan depletion in which we have previously demonstrated that the elevation of serum aldosterone precedes that of corticosterone. Sixty adult female Sprague-Dawley rats were fed either a low tryptophan diet or control diet for 4 (elevation of aldosterone only), 7 and 14 days (broader neuroendocrine activation) respectively. Gene expression of several adipogenic factors, CD31, interleukin-6, adiponectin, resistin and leptin were evaluated. Levels of mRNAs coding for adipogenic, angiogenic and inflammatory factors in adipose tissue were elevated at 4 and 7 days of tryptophan depletion. Additionally, gene expression of aldosterone sensing 11- $\beta$-hydroxysteroid dehydrogenase 2 and mineralocorticoid receptors were elevated. All changes disappeared at 14 days of tryptophan depletion. Synchronously an increase of adipose tissue mass was observed. Although direct evidence is not provided, observed changes in gene expression may be related to the action of aldosterone on mineralocorticoid receptors. Our findings represent the first data on any changes in gene expression in adipose tissue in animal models of depression.
\end{abstract}

Key words: Mineralocorticoid receptors - Adipose tissue - Gene expression - Animal model of depression

\section{Introduction}

Mineralocorticoid receptors (MRs), as nuclear receptors belong to the group of ligand-activated transcription factors (Arriza et al. 1987). Their primary function is to keep ion and water balance in the body by controlling the expression of the proteins responsible for ion and water transport, e.g. epithelial sodium channel $(\mathrm{ENaC})$ or $\mathrm{Na}^{+} / \mathrm{K}^{+}$pump (Fuller and Young 2005). Next to epithelial tissues, MRs are also present in non-epithelial tissues such as the heart, blood vessels (Funder 2005) and the brain (Geerling and Loewy 2009). MRs exert high affinity to a broad range of steroids (Joëls

Correspondence to: Daniela Jezova, Laboratory of Pharmacological Neuroendocrinology and Laboratory of Metabolic Regulations, Institute of Experimental Endocrinology, Biomedical Research Center, Slovak Academy of Sciences, 84505 Bratislava, Slovak Republic E-mail: daniela.jezova@savba.sk and de Kloet 1994; Myles and Funder 1996; de Kloet et al. 2000). Glucocorticoids circulate in much higher concentrations than mineralocorticoids e.g. aldosterone. Aldosterone selectivity in its target tissues requires intracellular activity of 11- $\beta$-hydroxysteroid dehydrogenase type 2 (HSD2), an enzyme which catalyzes the conversion of glucocorticoids to their inactive form with weak affinity for MRs (Funder et al. 1988; Isomura et al. 2006).

MRs are also expressed in the adipose tissue. Here they are involved in the process of adipogenesis. It is probable that MRs in adipose tissue are fully occupied by glucocorticoids. Predominant binding of glucocorticoids in adipocytes is supported by a low expression of HSD2 and a high expression of 11- $\beta$-hydroxysteroid dehydrogenase type 1 (HSD1) which has opposing catalytic activity as HSD2 (Feraco et al. 2013). However, there are indices that aldosterone is able to specifically stimulate differentiation of adipocytes under in vitro conditions (Rondinone et al. 1993). 
Elevated aldosterone concentrations have been observed in patients with obesity and metabolic syndrome (Garafova et al. 2014; Kargi and Iacobellis 2014). Therefore the understanding of aldosterone-adipose tissue interaction is of experimental and clinical relevance. Obesity is associated with chronic inflammation. Next to adipogenesis, both MRs and glucocorticoid receptors (GRs) are involved in the regulation of inflammatory processes, although their effects may be opposite. Interestingly, selective activation of GRs by dexamethasone inhibited while activation of MRs by aldosterone increased the expression of pro-inflammatory cytokines in mature white adipocytes (Hoppmann et al. 2010).

Unmasking the action of aldosterone itself in vivo is difficult because of high concentrations of glucocorticoids and variable HSD2 activity in cells of adipose tissue. Moreover, many physiological stimuli induce the release of glucocorticoids and mineralocorticoids simultaneously and both these steroids are increased under the stress conditions. When working on animal models of depression, we have recently observed that elevation of serum aldosterone precedes that of corticosterone in a model of diet-induced tryptophan (TRP) depletion in rats (Franklin et al. 2012, 2015). Additionally it was shown that 4 days of TRP depletion led to a rise in aldosterone secretion only. TRP depletion for 7-14 days resulted in an increase of both aldosterone and corticosterone concentrations (Franklin et al. 2015). In preliminary studies, we observed that prolonged exposure of rats to a low TRP diet resulted in an increase in the mass of the adipose tissue (unpublished data). Moreover, obesity could be associated with alterations in the TRP/kynurenine degradation pathway which may possibly be modified by pro-inflammatory cytokines locally at the adipose tissue (Wolowczuk et al. 2012).

The aim of the present study was to test the hypothesis that the processes related to adipogenesis are modified under the conditions associated with aldosterone elevation only. In this respect, we have evaluated gene expression of selected markers in a model of diet-induced TRP depletion for 4 days (aldosterone elevation only) and for 7-14 days (increased levels of both aldosterone and corticosterone).

\section{Material and Methods}

\section{Animals}

Adult female Sprague-Dawley rats (AnLab s.r.o., Prague, Czech Republic) aged 10 weeks (175-200 g) were used. They were housed in a temperature $\left(22 \pm 2^{\circ} \mathrm{C}\right)$ and humidity controlled room with a constant $12: 12 \mathrm{~h}$ light/dark cycle (lights on at 07:00 h). Animals were grouped 2 per cage with free access to food and water. All experimental procedures were approved by the Animal Health and Animal Welfare
Division of the State Veterinary and Food Administration of the Slovak Republic and conformed to the NIH Guidelines for Care and Use of Laboratory Animals.

\section{Model of tryptophan depletion}

Rats were fed either by low TRP (TRP-0.04\%) containing diet or by control diet $(0.2 \%$ TRP). The low TRP and equivalent control diets (Scientific Diet Supplies Ltd, Witham, Essex, UK) consisted of cereal product (34\%), vegetable protein (13\%), animal protein (5\%), energy source $(38 \%)$ and supplement (10\%). Diet was supplied in heavy-bottomed receptacles to avoid food spillage. Animals were fed by the control diet for 7 days prior to starting experimental procedures to adapt for this type of food, since the experimental diets were in a powder form rather than in the more standard pellet format.

\section{Design of experiment 1}

Animals were randomly assigned into the following groups ( $n=10$ per group): 1) rats fed the control diet for 4 days, 2) rats fed the control diet for 7 days, 3 ) rats fed the low TRP diet for 4 days, 4) rats fed the low TRP diet for 7 days. Rats remained in their home cages in the animal room for the complete period of investigation. Animals were sacrificed by decapitation at the end of each diet period. All experimental group time schedules within the study were synchronised to finish on the same day.

\section{Design of experiment 2}

Animals were randomly assigned into 2 groups ( $n=10$ per group): 1) rats fed the control diet for 14 days, 2) rats fed the low TRP diet for 14 days. Animals remained in their home cages in the experimental animal room for the complete period of investigation. Animals were killed by decapitation on day 15.

\section{Organ collection}

Animals were quickly moved to an adjacent room and killed by decapitation between $08.30-10.30 \mathrm{~h}$. Retroperitoneal adipose tissues were weighed and stored at $-70^{\circ} \mathrm{C}$ until required for analysis.

\section{$R N A$ isolation, reverse transcription and real-time PCR analysis}

Total RNA from retroperitoneal adipose tissue was isolated by TRIzol ${ }^{\oplus}$ Reagent (Life technologies, California, USA) according to manufacturer protocol. Isolated RNA $(1 \mu \mathrm{g})$ was reverse-transcribed using oligo (dT) nucleotides by 
ImProm-II reverse transcription system (Promega, Wisconsin, USA).

Primer Express 3.0 software was used to design primers specific for studied genes (Tab. 1). Real time qPCR was used for evaluation of mRNA concentration. Analysis was performed in a reaction volume of $20 \mu \mathrm{l}$ by GoTaq qPCR Master Mix (Promega, USA) as described previously (Babic et al. 2015). Primers (Tab. 1) were used at a concentration of $0.25 \mathrm{pmol} / \mu \mathrm{l}$. Reaction mix consisted of $10 \mu \mathrm{l} \mathrm{GoTaq} \mathrm{qPCR}$ Master Mix, $0.2 \mu \mathrm{l}$ ROX (Promega, USA), $1 \mu \mathrm{l}$ of forward and reverse primer (5 $\mu \mathrm{M}$ stock solution), 5-50 ng cDNA and water was added to the final reaction volume of $20 \mu \mathrm{l}$. qPCR was performed by Fast Real-Time PCR System 7900 HT (Applied Biosystems, USA). Initial denaturation at $95^{\circ} \mathrm{C}$ for $10 \mathrm{~min}$ was followed by 40 cycles at $95^{\circ} \mathrm{C}$ for $15 \mathrm{~s}, 60^{\circ} \mathrm{C}$ for $30 \mathrm{~s}$ and $72^{\circ} \mathrm{C}$ for $30 \mathrm{~s}$ respectively. Melting curve analysis for $20 \mathrm{~min}$ was performed and did not show any unspecific products of PCR. All data obtained by qPCR analysis from experiment 1 were evaluated as an ng of mRNA (cDNA) according to a standard curve and was normalized to gene expression of ribosomal protein subunit 29 (Rps29) as a reference gene. Gene expressions obtained from experiment 2 were evaluated by ${ }^{\Delta \Delta} \mathrm{Ct}$ calculation and normalized to Rps29 and beta tubulin gene (Tubb).

\section{Statistical analysis}

Data were first checked for the normality of distributions using the Shapiro-Wilks test. Non-normally distributed data were subjected to natural log transformations before parametric analyses were performed. Statistical significance

\section{A}

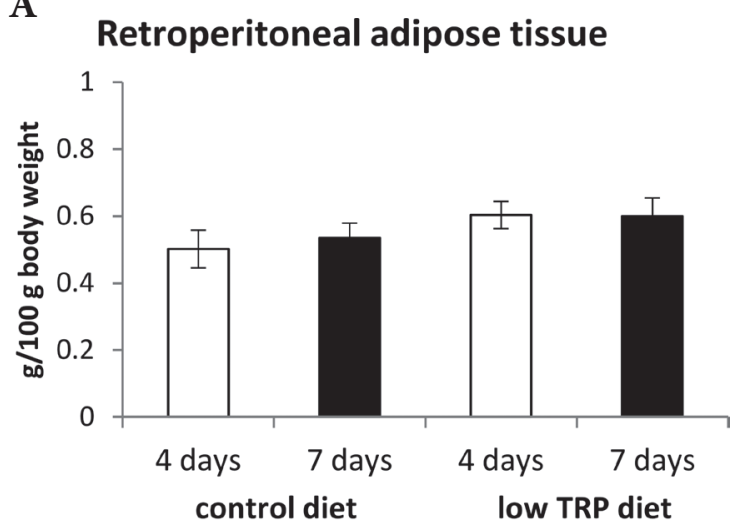

B

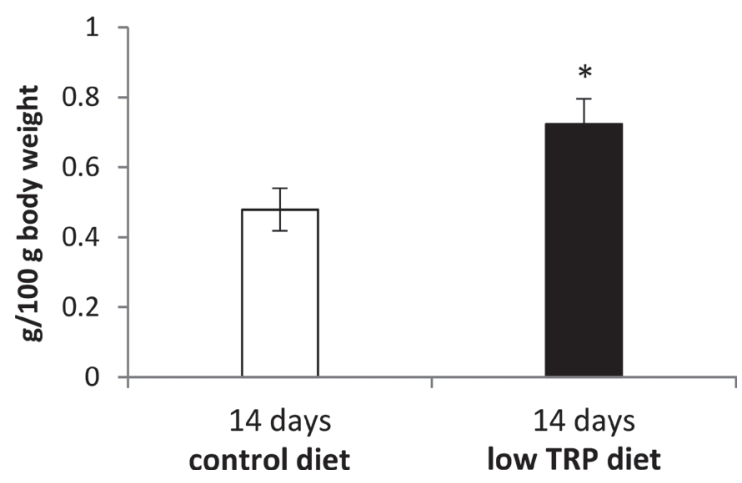

Figure 1. Effects of a low tryptophan (low TRP) diet for 4 or 7 days (A) and for 14 days (B) on relative weight of retroperitoneal adipose tissue. Each value represents the mean \pm SEM $(n=10$ rats/ group). Statistical significance as revealed by t-test for independent groups: ${ }^{\star} p<0.05$.

Table 1. Gene specific oligonucleotides for qPCR

\begin{tabular}{|c|c|c|}
\hline Gene & Forward primer & Reverse primer \\
\hline PPAR $\gamma$ & CATTTCTGCTCCACACTATGAA & CGGGAAGGACTTTATGTATGAG \\
\hline$a P 2$ & AGCGTAGAAGGGGACTTGGT & ATGGTGGTCGACTTTCCATC \\
\hline GLUT4 & TTTCCAGTATGTTGCGGATG & TCAGTCATTCTCATCTGGCC \\
\hline CD31 & CCCAGTGACATTCACAGACA & ACCTTGACCCTCAGGATCTC \\
\hline leptin & CCAGGATGACACCAAAACCCTC & ATCCAGGCTCTCTGGCTTCTGC \\
\hline adiponectin & GGCCGTGATGGCAGAGAT & CTTCCGCTCCTGTCATTCCA \\
\hline resistin & GGGACGTCCGTGAGGATACA & GGGCCGCTGTCCAGTCTA \\
\hline IL6 & CAAAGAAATGATGGATGCTTCCA & GGTAGAAACGGAACTCCAGAAGAC \\
\hline HSD1 & CCTCCATGGCTGGGAAAAT & GAACCCATCCAGAGCAAACTTG \\
\hline HSD2 & TCATGGACACATTCAGCTGTGA & TCACTGCCTCTGTCTTGAAGCA \\
\hline$M R$ & ACGTGTCAAGCTCTACTTTACGAA & TGACACCCAGAAGCCTCATC \\
\hline$T u b b$ & CCGTAGCCATGAGGGAAATCG & GGGACATACTTGCCACCTGTAG \\
\hline Rps29 & GCTGAACATGTGCCGACAGT & GGTCGCTTAGTCCAACTTAATGAA \\
\hline
\end{tabular}

Nucleotide sequence of primers used in gene expression evaluation of peroxisome proliferator-activated receptor gamma $(P P A R \gamma)$, fatty acid binding protein 4 (aP2), glucose transporter type 4 (GLUT4), platelet and endothelial cell adhesion molecule 1 (CD31), leptin, adiponectin, resistin, interleukin 6 (IL6), 11- $\beta$-hydroxysteroid dehydrogenase type 1 (HSD1), 11- $\beta$-hydroxysteroid dehydrogenase type 2 (HSD2), mineralocorticoid receptor (MR), $\beta$-tubulin (Tubb), and ribosomal protein subunit 29 (Rps29). 
PPARY

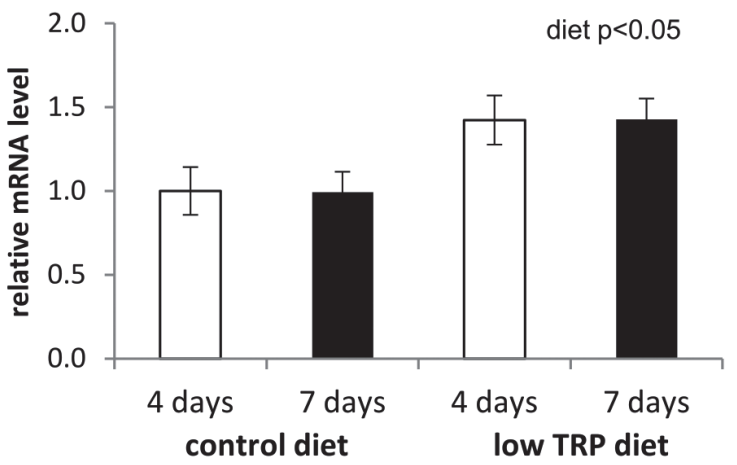

GLUT4

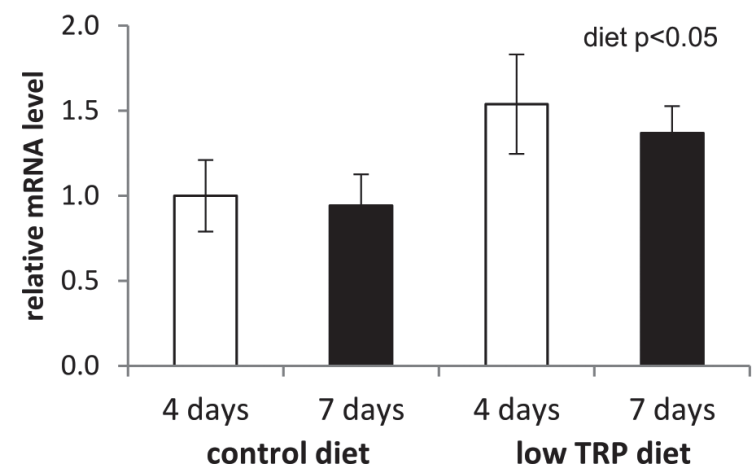

aP2

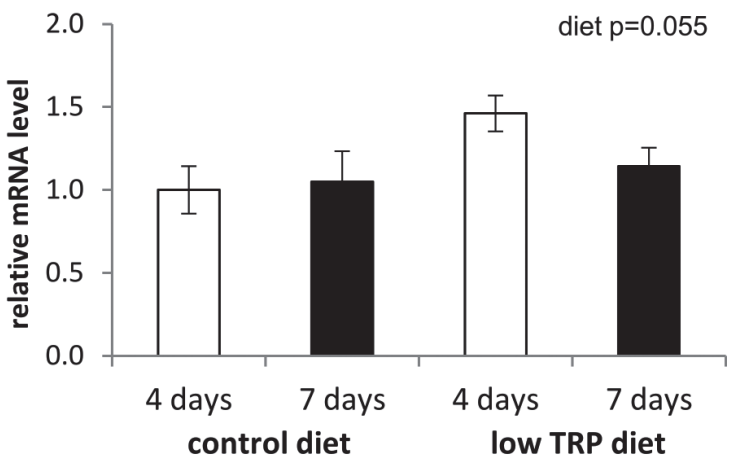

CD31

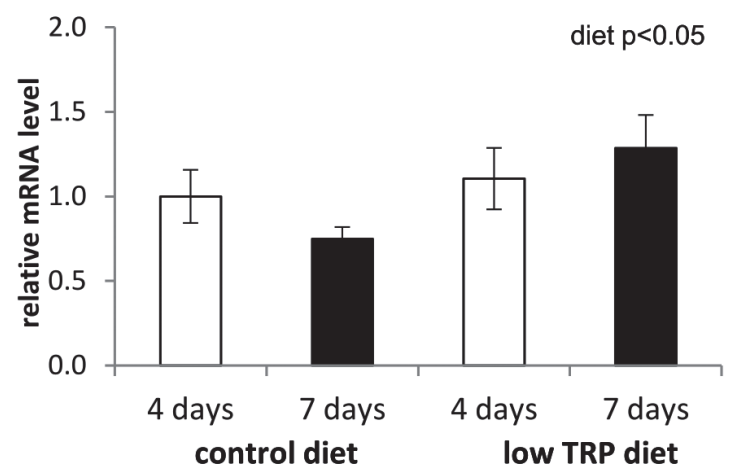

Figure 2. Changes in gene expression of peroxisome proliferator-activated receptor gamma (PPAR $\gamma$ ), glucose transporter type 4 (GLUT4), fatty acid binding protein type 4 (aP2) and platelet and endothelial cell adhesion molecule 1 (CD31) in the retroperitoneal adipose tissue at 4 and 7 days on control or low tryptophan (low TRP) diet. Expression of these genes was determined by qPCR. Obtained data were normalized to housekeeping gene Rps29. Each value represents the mean $\pm \operatorname{SEM}$ ( $n=10$ rats/group). The main effect of factor diet (control $v s$. low TRP diet) for PPAR $\gamma(p<0.05)$, GLUT4 $(p<0.05)$, CD31 $(p<0.05)$ and for aP2 $(p=0.055)$ as revealed by two-way ANOVA.

in experiment 1 was determined by two-way ANOVA for factors time (4 and 7 days) and diet (control and TRP-depleted). Whenever interaction reached significance, Tukey post hoc test was performed. Statistical analysis of data obtained from experiment 2 was performed by a t-test for independent groups. Results are expressed as mean \pm SEM. Overall level of significance was defined as $p<0.05$.

\section{Results}

Relative mass of retroperitoneal adipose tissue of animals fed by low TRP diet was unchanged at days 4 and 7 (Fig. 1A). However, prolonged exposure to the same diet for 14 days (Fig. 1B) caused a significant increase of relative mass of this tissue $\left(\mathrm{t}_{17}=-2.33, p<0.05\right)$.

Gene expressions of factors involved in adipose cells differentiation and angiogenesis were increased at 4 and 7 days on the low TRP diet. Measurements performed dur- ing the first week of low TRP diet demonstrated significant increases of mRNA concentration coding for adipogenic factors peroxisome proliferator-activated receptor gamma $(\operatorname{PPAR} \gamma)\left(\mathrm{F}_{1,36}=10.181, p<0.01\right)$ and glucose transporter type 4 (GLUT4) $\left(\mathrm{F}_{1,36}=4.9514, p<0.05\right)$ in comparison to those in control animals. Adipogenic factor fatty acid binding protein $(\mathrm{aP} 2)$ was partially increased $\left(\mathrm{F}_{1,36}=3.9222, p=\right.$ 0.055 ) at the days 4 and 7 on the low TRP diet versus control (Fig. 2). At similar time intervals angiogenic marker CD31 gene expression (Fig. 2$)$ was significantly increased $\left(\mathrm{F}_{1,35}=\right.$ 4.1372, $p<0.05)$.

Concentrations of mRNA coding for adiponectin $\left(\mathrm{F}_{1}\right.$, $35=4.6597, p<0.05)$, resistin $\left(\mathrm{F}_{1,36}=8.3509, p<0.01\right)$ and cytokine IL- $6\left(\mathrm{~F}_{1,33}=5.0366, p<0.05\right)$ were higher at 4 and 7 days of TRP depletion. Concentration of mRNA coding for leptin was increased but did not reach significance $\left(\mathrm{F}_{1,36}=\right.$ 3.4490, $p=0.071$ ) (Fig. 3). Adipose tissue gene expression of mineralocorticoid sensing enzyme HSD2 was increased at 4 and 7 days of TRP depletion $\left(\mathrm{F}_{1,36}=4.8886, p<0.05\right)$ 

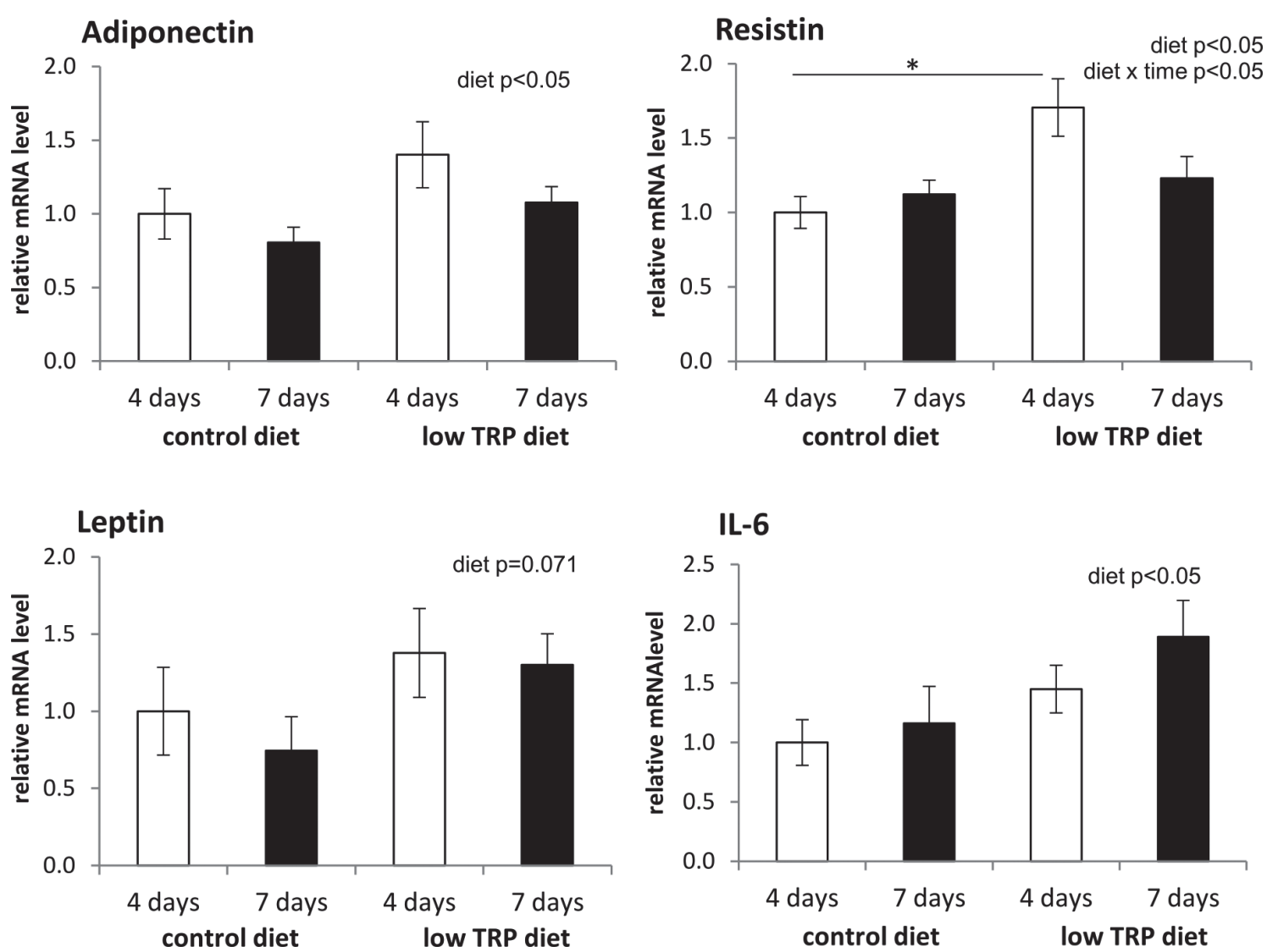

Figure 3. Changes in gene expression of adiponectin, resistin, leptin, interleukin 6 (IL-6) in the retroperitoneal adipose tissue at 4 and 7 days on control or low tryptophan (low TRP) diet. Expression of these genes was determined by qPCR. Obtained data were normalized to housekeeping gene Rps29. Each value represents the mean \pm SEM ( $n=10$ rats/group). The main effect of factor diet (control vs low TRP diet) for adiponectin $(p<0.05)$, resistin $(p<0.05)$, IL-6 $(p<0.05)$, leptin $(p<0.071)$ and a significant interaction of factors diet and time for resistin was revealed by two-way ANOVA. Analysis by Tukey post hoc test: ${ }^{\star} p<0.05$.

accompanied by a mild increase in mRNA concentrations of MRs $\left(F_{1,36}=3.9029, p=0.055\right)$. TRP depletion caused an increase of $\mathrm{mRNA}$ coding for glucocorticoid sensing enzyme HSD1 $\left(\mathrm{F}_{1,36}=23.698, p<0.001\right)$ in the retroperitoneal adipose tissue (Fig. 4).

TRP depletion for 14 days resulted in an increase of relative mass of rat compared to that in controls. None of the gene expressions of adipogenic and angiogenic factors measured were changed at day 14 (Tab. 2). Similarly, no changes in gene expression of MRs or HSD2 were observed after prolonged low TRP diet ingestion (data not shown). At the same time an increase of adipose tissue mass was observed (Fig. 1B).

\section{Discussion}

The present experiments demonstrate early changes in adipose tissue preceding its hypertrophy in rats on a low TRP diet. With respect to our previously reported increases of aldosterone but not of corticosterone in serum during the first week of TRP depletion (Franklin et al. 2015) it may be suggested that our observed changes in gene expression

Table 2. Gene expression of adipogenic and angiogenic factors at 14 days of control and low TRP diet

\begin{tabular}{lcc}
\hline Gene & $\begin{array}{c}\text { Control diet (a.u.) } \\
(\text { mean } \pm \text { SEM })\end{array}$ & $\begin{array}{c}\text { Low TRP diet (a.u.) } \\
(\text { mean } \pm \text { SEM })\end{array}$ \\
\hline PPARy & $1 \pm 0.057$ & $1.20 \pm 0.150$ \\
GLUT4 & $1 \pm 0.296$ & $1.18 \pm 0.279$ \\
aP2 & $1 \pm 0.103$ & $1.11 \pm 0.102$ \\
CD31 & $1 \pm 0.207$ & $0.601 \pm 0.110$ \\
\hline
\end{tabular}

Relative values (a.u.) of peroxisome proliferator-activated receptor gamma (PPAR $)$, fatty acid binding protein $4(a P 2)$, platelet and endothelial cell adhesion molecule $1(C D 31)$ and glucose transporter type 4 (GLUT4) gene expression. Ribosomal protein subunit 29 (Rps29) and $\beta$-tubulin (Tubb) were used as reference genes. 

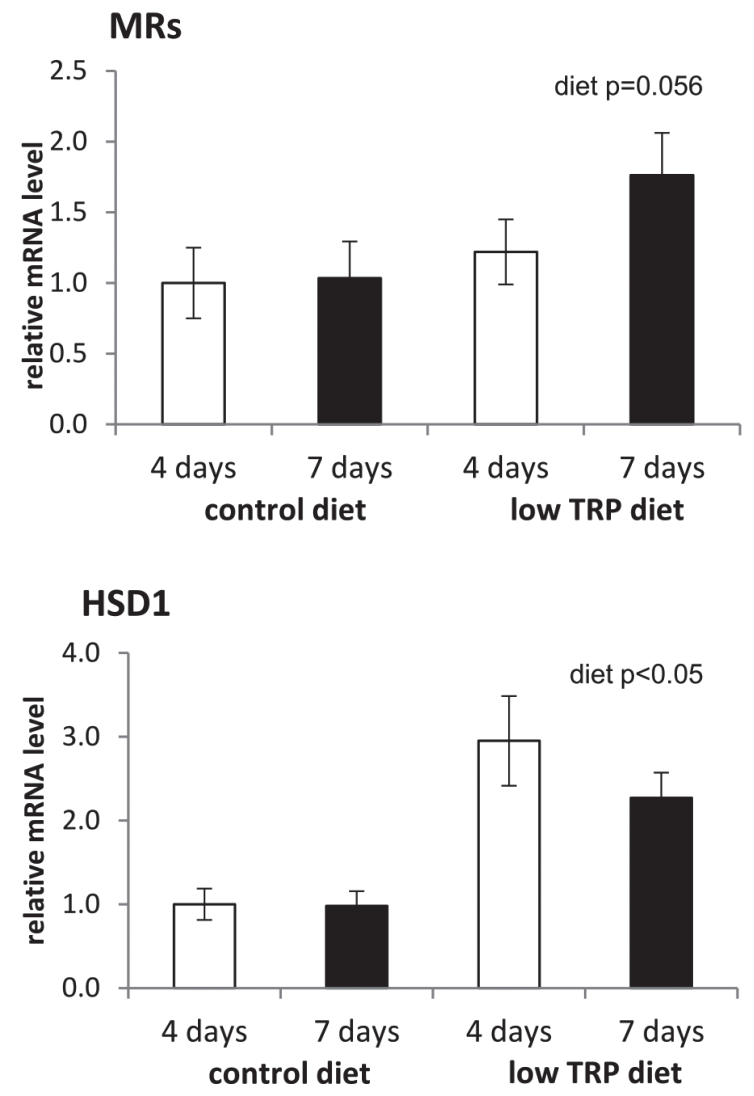

may be related to the action of aldosterone on MRs. More specifically, the levels of mRNAs coding for adipogenic, angiogenic and inflammatory factors in the adipose tissue were elevated at 4 and 7 days of TRP depletion. Whereas, such changes completely disappeared at the time of 14 days of the diet and was concomitant with an increase of adipose tissue mass.

The possibility that enhanced expression of adipogenic factors observed in the present study could be attributed to the action of aldosterone on MRs is supported by the data obtained in in vitro studies (Armani et al. 2015). It was previously reported that MRs activation upregulated the expression of adipocyte markers, e.g. adiponectin, leptin, resistin, PPAR $\gamma$, IL-6, and promoted adipogenesis in 3T3L1 adipose cells (Caprio et al. 2007; Guo et al. 2008). Accordingly, inhibition of MRs transcriptional activity by the MRs antagonist drospirenone reduced transcript levels of the pro-adipogenic genes in human adipocyte cultures (Caprio et al. 2011).

In the present study, changes in adipocyte marker gene expression were observed at 4 and 7 days of TRP depletion and in synchrony with increases of serum aldosterone but not of corticosterone. The changes in gene expression previously stated disappeared after 14 days of the diet, at the time

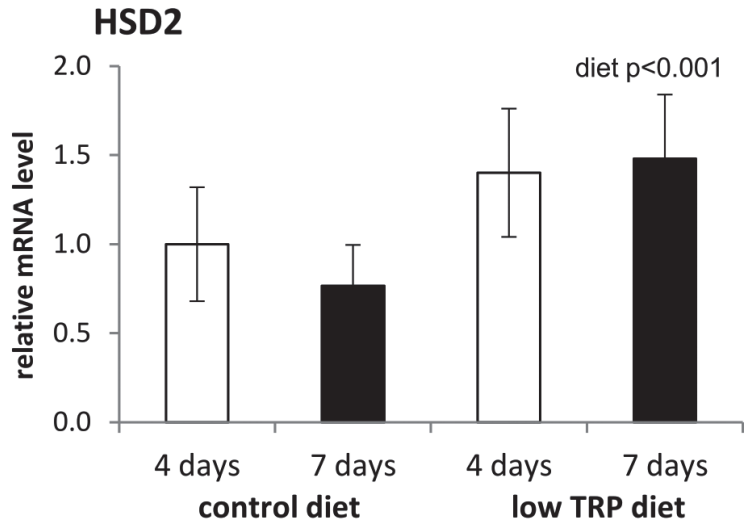

Figure 4. Changes in gene expression of mineralocorticoid receptors (MRs), 11- $\beta$-hydroxysteroid dehydrogenase type 2 (HSD2) and 11- $\beta$-hydroxysteroid dehydrogenase type 1 (HSD1) enzyme in the retroperitoneal adipose tissue at 4 and 7 days on control or low tryptophan (low TRP) diet. Expression of these genes was determined by qPCR. Obtained data were normalized to housekeeping gene Rps29. Each value represents the mean \pm SEM ( $n=$ 10 rats/group). The main effect of factor diet (control $v s$. low TRP diet) for HSD1 $(p<0.05)$, HSD2 $(p<0.001)$ and MRs $(p=0.056)$ as revealed by two-way ANOVA.

of broader neuroendocrine activation (Franklin et al. 2015). Moreover, the rise in the levels of mRNA coding for MRs in the adipose tissue also disappeared at the day 14 together with augmentation of fat tissue mass. Activation of MRs is generally considered to negatively influence adipocyte differentiation and metabolism. This statement is supported mainly by studies evaluating the effects of aldosterone or other MRs agonists in genetically or diet-induced obese animals or humans (Armani et al. 2015). However, there is a recent report on a paradoxical resistance to high-fat dietinduced obesity in lean MRs-overexpressing mice (Kuhn et al. 2014). Positive effects of MRs activation on adipogenesis are further supported by experiments of Martinéz-Martinéz et al. (2015). The authors investigated the consequences of prolonged treatment with aldosterone on adipocyte marker gene expression in lean, non-obese mice. Consistent with the results of the present study at 4 and 7 days, aldosterone treatment induced a rise in PPAR $\gamma, \mathrm{aP} 2$ and leptin gene expression without an increase in the fat tissue mass. Thus, the findings of the present study are in support of the positive effects of MRs activation on adipocyte function. Accordingly, the fat tissue mass enlargement occurred in the absence of increased gene expression of MRs and adipogenic factors at 14 days of TRP depletion. 
A very positive and underpinning finding to our hypothesis on the role of aldosterone in the adipogenesis, is the rise in gene expression of the mineralocorticoid action promoting enzyme HSD2. This enzyme is particularly expressed in the endothelial and vascular smooth cells of the adipose tissue (Essick and Sam 2011). However, in the present experiments the rise in HSD2 gene expression was accompanied also by a rise in mRNA levels coding for HSD1, which is known to predispose the adipocytes to glucocorticoid-mediated signalling (Feraco et al. 2013). We may speculate that due to the very high expression of HSD1 and relatively low expression of HSD2 in the adipocytes, these changes in the latter enzyme may be of higher functional significance. Experiments evaluating the kinetics of relevant enzymatic reactions are needed to better understand these phenomena.

In conclusion, low TRP diet-induced rise in serum aldosterone is associated with enhanced gene expression of adipogenic factors, MRs and HSD, without changes in fat tissue mass. Longer periods of TRP depletion induced broader neuroendocrine activation, enhancement of adipose tissue mass without activation of gene expression of adipocyte markers. Even though direct evidence for a role of aldosterone in the described processes was not found, present results represent the first data on any changes in the adipose tissue in TRP depletion model of depression or animal models of depression in general. Evidence on the involvement of aldosterone in the development and outcome of depression in animal models and patients is ever increasing (Hlavacova et al. 2012; Büttner et al. 2015).

Acknowledgements. The studies were supported by grants from Oxford Brookes University HEIF 4 and HEIF 5 funding and VEGA 2/0128/14.

\section{References}

Armani A., Marzolla V., Fabbri A., Caprio M. (2015): Cellular mechanisms of MR regulation of adipose tissue physiology and pathophysiology. J. Mol. Endocrinol. 55, R1-10 http://dx.doi.org/10.1530/JME-15-0122

Arriza J. L., Weinberger C., Cerelli G., Glaser T. M., Handelin B. L., Housman D. E., Evans R. M. (1987): Cloning of human mineralocorticoid receptor complementary DNA: structural and functional kinship with the glucocorticoid receptor. Science 237, 268-275 http://dx.doi.org/10.1126/science.3037703

Babic S., Pokusa M., Danevova V., Ding S. T., Jezova D. (2015): Effects of atosiban on stress-related neuroendocrine factors. J. Endocrinol. 225, 9-17 http://dx.doi.org/10.1530/JOE-14-0560

Büttner M., Jezova D., Greene B., Konrad C., Kircher T., Murck H. (2015): Target-based biomarker selection - Mineralocorticoid receptor-related biomarkers and treatment outcome in major depression. J. Psychiatr. Res. 66-67, 24-37 http://dx.doi.org/10.1016/j.jpsychires.2015.04.012

Caprio M., Fève B., Claës A., Viengchareun S., Lombès M., Zennaro M. C. (2007): Pivotal role of the mineralocorticoid receptor in corticosteroid-induced adipogenesis. FASEB J. 21, $2185-2194$ http://dx.doi.org/10.1096/fj.06-7970com

Caprio M., Antelmi A., Chetrite G., Muscat A., Mammi C., Marzolla V., Fabbri A., Zennaro M. C., Fève B. (2011): Antiadipogenic effects of the mineralocorticoid receptor antagonist drospirenone: potential implications for the treatment of metabolic syndrome. Endocrinology 152, 113-125 http://dx.doi.org/10.1210/en.2010-0674

de Kloet E. R., Van Acker S. A., Sibug R. M., Oitzl M. S., Meijer O. C., Rahmouni K., de Jong W. (2000): Brain mineralocorticoid receptors and centrally regulated functions. Kidney Int. 57, 1329-1336 http://dx.doi.org/10.1046/j.1523-1755.2000.00971.x

Essick E. E., Sam F. (2011): Cardiac hypertrophy and fibrosis in the metabolic syndrome: A role for aldosterone and the mineralocorticoid receptor. J. Hypertens. 2011, 346985 http://dx.doi.org/10.4061/2011/346985

Feraco A., Armani A., Mammi C., Fabbri A., Rosano G. M. C., Caprio M. (2013): Role of mineralocorticoid receptor and rennin-angiotensin-aldosterone system in adipocyte dysfunction and obesity. J. Steroid. Biochem. 137, 99-106 http://dx.doi.org/10.1016/j.jsbmb.2013.02.012

Franklin M., Bermudez I., Hlavacova N., Babic S., Murck H., Schmuckermair C., Singewald N., Gaburro S., Jezova D. (2012): Aldosterone increases earlier than corticosterone in new animal models of depression: is this an early marker? J. Psychiatr. Res. 46, 1394-1397 http://dx.doi.org/10.1016/j.jpsychires.2012.07.010

Franklin M., Hlavacova N., Babic S., Pokusa M., Bermudez I., Jezova D. (2015): Aldosterone signals the onset of depressive behaviour in a female rat model of depression along with SSRI treatment resistance. Neuroendocrinology 102, 274-287 http://dx.doi.org/10.1159/000431152

Fuller P. J., Young M. J. (2005): Mechanisms of mineralocorticoid action. Hypertension 46, 1227-1235 http://dx.doi.org/10.1161/01.HYP.0000193502.77417.17

Funder J. W., Pearce P. T., Smith R., Smith A. I. (1988): Mineralocorticoid action: target tissue specificity is enzyme, not receptor, mediated. Science 242, 583-585

http://dx.doi.org/10.1126/science.2845584

Funder J. W. (2005): Mineralocorticoid receptors: distribution and activation. Heart. Fail. Rev. 10, 15-22

http://dx.doi.org/10.1007/s10741-005-2344-2

Garafova A., Penesova A., Cizmarova E., Marko A., Vlcek M., Jezova D. (2014): Cardiovascular and sympathetic responses to a mental stress task in young patients with hypertension and/ or obesity. Physiol. Res. 63, S459-467

Geerling J. C., Loewy A. D. (2009): Aldosterone in the brain. Am. J. Physiol-Renal. 297, 559-576 http://dx.doi.org/10.1152/ajprenal.90399.2008

Guo C., Ricchiuti V., Lian B. Q., Yao T. M., Coutinho P., Romero J. R., Li J., Williams G. H., Adler G. K. (2008): Mineralocorticoid receptor blockade reverses obesity-related changes in expression of adiponectin, peroxisome proliferator-activated 
receptor-gamma, and proinflammatory adipokines. Circulation 117, 2253-2261 http://dx.doi.org/10.1161/CIRCULATIONAHA.107.748640

Hlavacova N., Wes P. D., Ondrejcakova M., Flynn M. E., Poundstone P. K., Babic S., Murck H., Jezova D. (2012): Subchronic treatment with aldosterone induces depression-like behaviours and gene expression changes relevant to major depressive disorder. Int. J. Neuropsychopharmacol. 15, 247-265 http://dx.doi.org/10.1017/S1461145711000368

Hoppmann J., Perwitz N., Meier B., Fasshauer M., Hadaschik D., Lehnert H., Klein J. (2010): The balance between gluco- and mineralo-corticoid action critically determines inflammatory adipocyte responses. J. Endocrinol. 204, 153-164 http://dx.doi.org/10.1677/JOE-09-0292

Isomura Y., Mune T., Morita H., Suwa T., Takada N., Yamamoto Y., Takeda J. (2006): Physiologic roles of 11beta-hydroxysteroid dehydrogenase type 2 in kidney. Metabolism 55, 1352-1357 http://dx.doi.org/10.1016/j.metabol.2006.06.005

Joëls M., de Kloet E. R. (1994): Mineralocorticoid and glucocorticoid receptors in the brain. Implications for ion permeability and transmitter systems. Prog. Neurobiol. 43, 1-36 http://dx.doi.org/10.1016/0301-0082(94)90014-0

Kargi A. Y., Iacobellis G. (2014): Adipose tissue and adrenal glands: novel pathophysiological mechanisms and clinical applications. Int. J. Endocrinol. 2014, 614074 http://dx.doi.org/10.1155/2014/614074

Kuhn E., Bourgeois C., Keo V., Viengchareun S., Muscat A., Meduri G., Le Menuet D., Fève B., Lombès M. (2014): Paradoxical resistance to high-fat diet-induced obesity and altered macrophage polarization in mineralocorticoid receptor-overexpressing mice. Am. J. Physiol. Endocrinol. Metab. 306, E75-90

http://dx.doi.org/10.1152/ajpendo.00323.2013

Martínez-Martínez E., Cachofeiro V., Rousseau E., Álvarez V., Calvier L., Fernández-Celis A., Leroy C., Miana M., JuradoLópez R., Briones A. M., et al. (2015): Interleukin-33/ST2 system attenuates aldosterone-induced adipogenesis and inflammation. Mol. Cell. Endocrinol. 15, 20-27 http://dx.doi.org/10.1016/j.mce.2015.04.007

Myles K., Funder J.W. (1996): Progesterone binding to mineralocorticoid receptors: in vitro and in vivo studies. Am. J. Physiol. 270, 601-607

Rondinone C. M., Rodbard D., Baker M. E. (1993): Aldosterone stimulated differentiation of mouse 3T3-L1 cells into adipocytes. Endocrinology 132, 2421-2426

Wolowczuk I., Hennart B., Leloire A., Bessede A., Soichot M., Taront S., Caiazzo R., Raverdy V., Pigeyre M., ABOS Consortium, Guillemin G. J., Allorge D., Pattou F., Froguel P., Poulain-Godefroy O. (2012): Tryptophan metabolism activation by indoleamine 2,3-dioxygenase in adipose tissue of obese women: an attempt to maintain immune homeostasis and vascular tone. Am. J. Physiol. Regul. Integr. Comp. Physiol. 303, R135-143

http://dx.doi.org/10.1152/ajpregu.00373.2011

Received: December 19, 2015

Final version accepted: February 13, 2016

First published online: June 2, 2016 